\title{
pÿ I have better stuff at home : Treasure hunting and private collecting of World War II artefacts in Finnish Lapland
}

\section{Herva, Vesa-Pekka}

2016-06-28

pÿHerva , V-P , Koskinen-Koivisto , E , Seitsonen , O \& Thomas , S 2016 , ' I have better stuff pÿat home : Treasure hunting and private collecting of World War II artefacts in Finnish Lapland ', World Archaeology , vol. 48 , no. 2 , pp. 267-281 . https://doi.org/10.1080/00438243.2016.1184586

http://hdl.handle.net/10138/300353

https://doi.org/10.1080/00438243.2016.1184586

acceptedVersion

Downloaded from Helda, University of Helsinki institutional repository.

This is an electronic reprint of the original article.

This reprint may differ from the original in pagination and typographic detail.

Please cite the original version. 
Vesa-Pekka Herva, Eerika Koskinen-Koivisto, Oula Seitsonen \& Suzie Thomas (2016) 'I have better stuff at home': treasure hunting and private collecting of World War II artefacts in Finnish Lapland, World Archaeology, 48:2, 267-281

This is an Accepted Manuscript of an article published by Taylor \& Francis in World Archaeology 28 June 2016, available online: https://www.tandfonline.com/doi/full/10.1080/00438243.2016.1184586

\begin{abstract}
Almost all archaeologists encounter collectors of different kinds of artefacts at some point in their career, whether it is the private collectors of financially valuable antiquities or 'amateur archaeologists' who have amassed personal collections of local finds. In our research into the material legacy of the German presence in northern Finland during World War II, we have encountered both artefact hunters (primarily but not exclusively metal detecting enthusiasts) and artefact collectors (sometimes the same people) with a specific interest in military remains from this location and period. In this article, we explore these alternative perspectives on collecting, and frame them within the context of treasure hunters, militaria collectors and other history hobbyists, and their relationship to the 'official' heritage managers and curators.
\end{abstract}

\title{
KEYWORDS
}

Collectors; alternative archaeology; artefact hunters; Finnish Lapland; metal detecting; World War II

\section{Introduction}

It was at one of our public talks in Finnish Lapland that a local man came over to inspect the excavation finds connected to World War II (WWII) that we had on display. 'I have better stuff at home', he casually commented. He later explained that he was very familiar with this sort of material, as it had always been present in his environment, and that as he had got older he had begun to take more of an interest in the WWII history and heritage around him. His remark is characteristic of several, although not all, of the perspectives of local individuals when discussing the remains from this period of history.

Collecting, particularly by hobbyist treasure hunters, creates a range of dilemmas for archaeologists; questions of how to engage with 'avocational archaeologists' and 'amateur archaeology collectors' are popular themes for ethical debates in archaeology classes (e.g. Colwell-Chantonphonh, Hollowell, and McGill 2008). In Finnish Lapland, people have become interested in the material remains from the 1940-45 German military presence in the region. This interest has included often unauthorized and undocumented collecting of war-related artefacts from the landscape. The motivations to engage with this material heritage have included its status as 'dark' heritage but also link to its local historical relevance and the period's presence in living memory and in stories passed on from previous generations (Sääskilahti 2013). In other cases, as the opening anecdote demonstrates, individuals do not start from a 'heritagized' perspective at all, but collect, move or otherwise interact with WWII heritage due to its simply 'being there'.

Two key questions guide this article: what are the drivers for avocational/amateur WWII artefact collecting in Finland, especially Lapland? And what is the relationship between these collectors and the authorities responsible for cultural heritage management? In this context, the 'responsible authorities' are the national and regional government organizations involved with cultural heritage management (e.g. Museovirasto, 
the National Board of Antiquities [NBA] and Metsähallitus, the Forestry Commission), as well as museum professionals. This article shows that while there are certainly collectors, in Finland and elsewhere, who favour well-preserved militaria and memorabilia (which can fetch high prices), there are also hobbyist treasure hunters who themselves search for WWII militaria in the landscape, and collect, keep and sometimes trade this material. This is almost always of less financial value than the 'pristine' material that has not been in the ground, and consequently is of little interest to 'high-end' collectors. However, it is likely that the experiences attached to the discoveries of 'low-end' material, more so than the financial incentives, represent the strongest motivations.

We deliberately refer to these 'low-end' artefact collectors as 'treasure hunters', rather than 'metal detectorists' or 'looters' because people who search for WWII material in the Lapland wilderness refer to themselves as 'treasure hunters' (aarteenetsijä in Finnish). Dismissing these activities as 'looting' not only runs the risk of overlooking the contribution they could potentially make to research, but also misses an opportunity to understand more fully the motivations and ontologies presented by these different modes of engagement (Hart and Chilton 2015; Pitblado 2014). We also use the term 'alternative archaeology' to describe these activities, because it captures important aspects of treasure hunting as they appear to us. Although associated with fringe or pseudoarchaeology, alternative archaeology can usefully be employed in this broader sense to represent alternative perspectives to those of heritage professionals.

Within a number of different types of engagement with the WWII heritage there appear to be two different kinds of collectors emerging from our research: 'serious collectors' and 'treasure hunters' (KoskinenKoivisto and Thomas, forthcoming, and below). Serious collectors focusing on acquiring material that is in good condition are rarely interested in the rusty, weathered material found abundantly on the sites themselves. On the other hand, treasure hunters value being out in the wilderness and 'discovering' these exposed objects (see also Thomas, Seitsonen, and Herva, 2016). In this article, we situate these different collection activities, considering both low- and high-end collecting, within the context of both 'alternative' archaeologies and the 'official' management and research strategies of museums and national heritage agencies. Moving on, we discuss the appeal of treasure hunting, militaria collecting and other forms of nonacademic and alternative engagement with WWII German material heritage in northern Finland.

\section{Collecting in context}

Artefact collecting has traditionally gone hand in hand with scholarly research. Griffin $(1999,103-105)$ has noted the significant role of individual collectors in establishing museums and collections that have gone on to become important resources for scholars, community groups and the wider public. Similarly, the relationship between the academy and collectors is well documented in natural history (e.g. Porter 2008). Other literature has drawn attention to the potential for museum/collector collaborations to facilitate looting of archaeological sites and illegal smuggling of cultural objects (e.g. Bowman 2008; Manacorda and Chappell 2011). While much of this research has focused on transnational movement of objects, often fetching high prices, some researchers have also discussed the ethics and research implications of museums and other heritage authorities engaging with hobbyist treasure hunters, especially metal detectorists (e.g. Rasmussen 2014; Robbins 2013). Another pertinent issue is the way in which collectors, treasure hunters and other non-professionals choose to focus on different aspects of history and heritage to those that heritage professionals select for study or preservation. Avocational collectors and treasure hunters may even feel they are protecting or 'rescuing' aspects of cultural heritage otherwise ignored or excluded by the authorities.

We have interviewed various WWII enthusiasts in selected areas of Finnish Lapland (Table 1). We are deliberately vague about the exact locations of our informants to protect their identities. All hobbyists we 
interviewed had a long-term interest in war history, especially WWII, and we have identified different types of enthusiasts through a 'continuum of interests' (Figure 1; Koskinen-Koivisto and Thomas, forthcoming). Under an umbrella term of 'history hobbyists', we have found that our informants fell into the categories of 'Expert-Guides', 'Expert-Explorers', 'Expert-Activists' and 'Expert-Collectors', acknowledging that there is sometimes significant overlap between these different groups. Activities that different interest groups and individuals carry out can include independently developing tourism attractions utilizing WWII material, community-based site stewardship and also the 'serious leisure' activities of collecting and treasure hunting. The 'serious collectors' and 'treasure hunters' that we identified for this article fall roughly within the continuum categories of 'Expert-Explorer' and 'Expert-Collector'. Interviewees had different perceptions of how to 'rescue' objects, and about what to do with them once rescued. In one instance, a history hobbyist who may be characterized as an 'Expert-Activist' set up a society with a fellow enthusiast. Many others also belong to larger organizations, such as Rotary clubs, with some of these organizations more 'official' than others in their nature.

Table 1. A summary of the interviewees' role, gender, age and relationship to collecting and other forms of engagement with WWII heritage in Finnish Lapland.

Figure 1. A classification of the different roles of WWII history hobbyists in Finnish Lapland.

\section{The legacy of WWII in northern Finnish mindscapes and landscapes}

The abundance of WWII German military material in Lapland landscapes (Figure 2) and local perceptions of these remains must be understood in relation to the military and other history of the region. After the three-month 'Winter War' (1939-40) against the Soviet Union, Finland turned to Germany for material and other assistance in anticipation of a new conflict with its eastern neighbour. Finland thus came to cooperate with Germany, including assisting Germany's attack on the Soviet Union in 1941, although the two countries were not formally allied. Finland allowed German troops to operate against the Soviet Union from Finnish territory. Over 200,000 German troops (more than there were inhabitants in Lapland at the time) and their ca. 30,000 prisoners of war came to be based in the northern parts of the country. In 1944, however, Finland turned against Germany due to Soviet pressure and the so-called 'Lapland War' broke out between the former brothers-in-arms. The German troops retreated northwards and evacuated to German-occupied Norway, destroying their own military sites and inflicting vast destruction on the northern Finnish infrastructure, settlements and property (see e.g. Mann and Jörgensen 2002; Alftan 2005; Tuominen 2005).

The complicated Finnish-German relations - first as much-needed (if embarrassing) friends and then enemies - explain why Finns have tried to distance themselves, since the war, from the German war efforts and have been reluctant to engage too closely with this aspect of national history. The situation has recently started to change, however, with more attention directed to previously marginalized WWII experiences in Finnish Lapland. An example of this, discussed elsewhere (e.g. Koskinen-Koivisto and Thomas, forthcoming; see also Forrest 2015) is the temporary exhibition Wir waren Freunde ('We Were Friends') at the Provincial Museum of Lapland in Rovaniemi. Launched in April 2015 to commemorate the 70th anniversary of the end of WWII, and ending in January 2016, the exhibition focused on the experience of local communities and German soldiers in Lapland during the war. Nonetheless, many northern inhabitants still feel that their WWII legacy, to a large part related to the German presence, has been neglected in comparison to the experiences further south.

Figure 2. Discarded and destroyed German military material in the Lapland wilderness near Inari. Photo: Oula Seitsonen. 
The German military presence in Finland had significant impacts, especially on northern Finnish mindscapes and landscapes. On the one hand, local inhabitants were generally on amicable terms with the German troops (Aikio-Puoskari and Magga 2010), interacted with them on a daily basis and benefited from their presence in various ways. On the other hand, however, the retreating German troops inflicted large-scale destruction. There are thousands of more or less thoroughly destroyed German sites in northern Finland and enormous quantities of destroyed military material that the Germans left behind. While largely cleared up after the war, plenty is still to be found in various parts of Lapland, with local inhabitants frequently aware of the material's enduring presence. It was, however, intentionally 'forgotten' about until about a decade ago.

That said, locals and tourists venturing to the 'exotic' north would have encountered and likely engaged with such sites and material culture. WWII sites are generally not protected by Finnish cultural heritage legislation. Still, retrieving objects from these sites is not permitted in principle, as all military material in and on the ground is owned by the defence forces. In practice, German sites are often open to militaria hunters.

Finnish legislation guarantees access to both privately owned and state-owned land (for recreational purposes, such as berry and mushroom picking), whereas all digging is forbidden without the landowner's permission. The combination of the relative remoteness and inaccessibility of many German sites means there is little risk of getting caught for WWII treasure hunting.

\section{Low-end collecting and 'alternative archaeology'}

Unauthorized digging at archaeological/heritage sites is generally understood within archaeological discourse as 'looting', with the implication that it is motivated by a desire to acquire objects for personal collections or antiques markets. This view on unauthorized digging is evidently derived from the world of high-end collecting. Signs of unauthorized digging (treasure hunting) are commonly encountered at WWII sites in northern Finland. Some of these signs seem to be many years old, although we have also found fresh pits at several sites visited over the last few years, most recently in the summer of 2015 (Figure 3). Likewise, we have frequently come across 'sorting stations' where finds (pottery and glassware in particular) have been collated and assessed (Figure 4), apparently to identify pieces with stamps, which have been taken away, leaving behind the 'uninteresting' fragments.

While signs of treasure hunting are often evident, the motivations for this activity, and what happens to the finds that are taken away, are not entirely clear. Our interviews suggest that serious militaria collectors have generally very little interest in such finds, although they may sometimes possess an occasional specimen. The supply of clearly excavated finds at Finnish arms fairs is very limited. Internet searches have likewise shown that although ground finds (usually of unstated and unclear origins) are available, the emphasis is on good-condition artefacts. However, whether the objects connected to the 'sorting stations' mentioned above are removed to become parts of personal collections or for trade is unknown. We know from our interviews that treasure hunted objects are mostly kept as personal mementos, although occasionally the collectors exchange these pieces in face-to-face meetings.

It seems highly likely that a substantial portion of the material taken away becomes part of the collections (of whatever kind) of treasure hunters themselves, and perhaps their circles of like-minded friends, although those we talked to showed little interest in finds such as porcelain sherds with stamps. Indeed, they tended to downplay the importance of accumulating collections and indicated, instead, that they only keep selected pieces. It is possible that the 'sorting station' activities documented at sites may be associated with a younger generation of treasure hunters, whom we have had little success in contacting so 
far. Furthermore, based on interviewee remarks, it seems that at least some treasure hunters come from abroad to search for artefacts, suggesting a touristic element to the activity (cf. Thomas, Seitsonen, and Herva, 2016). It appears that the reasons for searching for low-end militaria are very different to those for the looting of high-end objects, even if there are some markets for the former as well. In this view, artefacts taken from WWII sites can usefully be understood as treasure hunters' 'souvenirs' from alternative archaeological adventures at former military sites.

Figure 3. A 'looting pit' at a German military base in Lautavaara near Rovaniemi. This particular pit was apparently not a 'fresh' one, but signs of both very recent and older illicit digging were in evidence at the large and easily accessible site of Lautavaara. Photo: Vesa-Pekka Herva.

Another implication is that treasure hunting is not solely, nor perhaps even primarily, about acquiring objects for personal or other people's collections. Rather, the very hunt itself and the excitement of discovering things is an important motivation. Treasure hunting may thus bear similarities to, for instance, 'urban exploration', which entails adventuring in abandoned and closed-off buildings (Garrett 2015). The proposed view on unauthorized engagements with military sites also resonates with popular images of archaeology as a treasure hunt (Holtorf 2004, 47). The search for artefacts at military sites - often located in natural and even 'wilderness' settings in Finnish Lapland - provides an opportunity to participate personally in such adventurous practices.

Indeed, not all the hobbyists that we interviewed identified themselves as collectors, and/or were reluctant to show their 'collections' to us. These history hobbyists did, however, have other alternative engagements with WWII objects: some of them took part in attempts to rescue objects to display to the public at local sites, tourist attractions or even museums. The treasure hunters we met did not show us a coherent or organized collection, but rather samples of artefacts they had found and/or photos of their discoveries. Sometimes they did not even collect their discoveries, but instead just documented them and the associated structures through photography. These 'alternative archaeologists' seemed to value the experience of discovery based on their archival and map searches, and shared a love of the wilderness. One told us that, 'it's great to spend time in nature, to put up a tent and look around. [...] In the summers when I was most active in this respect, I used up two pairs of rubber boots just walking in the wilderness'. Through visiting and searching different sites, they engaged with a tangible connection with the local heritage 'their' heritage.

In Finnish Lapland, treasure hunters' relationships to the artefacts seem therefore to be personal - not about collecting for the sake of it or for financial benefits. Indeed, most of our interviewees - whether collectors or those otherwise interested in WWII and German material heritage - had some direct or indirect personal connection to German troops in Finland and/or their material culture, connections which they often pinpointed as having sparked off their collecting or other encounters with WWII heritage. These personal connections came in many forms and included, for instance, having a family connection to Finnish SS men and contributing to their official remembrance (Olsson, Kokkila, and Hakanpää 1999), a personal relationship with a Finnish official who had served with the Germans during the war, or finding and playing with German military objects (not infrequently explosives) as children. While we are yet to interview any of the visiting 'tourist' treasure hunters mentioned above, our informants estimated that the majority of these come from either southern Finland or Germany, and so it is possible to speculate, pending further research, that these individuals also feel some kind of personal connection to the WWII heritage (see also Carr in this issue).

Figure 4. A treasure hunter's 'sorting station' at a German site near Rovaniemi. Photo: Vesa-Pekka Herva.

Many of the interviewees appreciated detailed information about the sites, such as battlefields/prisoner of war camps/military bases, and the artefacts they have found. One especially looked for and collected 
helmets, whereas another was interested in common everyday, portable and easily found artefacts such as belt buckles. Those falling into the 'Expert-Explorers' part of the continuum in particular tended to study books and maps over the winter and thereby prepare for the summer season. Many also visited archives, such as the War Archive, to research battlefields. Our interviewees were not too keen to talk about the markets, but some noted that previous dealings between collectors had revolved around arms fairs, whereas now the internet and personal contacts were more important. Two collectors that we talked with, who had previously attended these fairs, think that today fairs are full of fake items. It is more reliable to buy from somebody who can give a provenance and history to go with the objects. According to one informant: 'About $90 \%$ of the stuff sold on the internet and at fairs are fakes. I think that is shit, it is business. They make them in low-cost countries such as China. They make very high quality badges, fake ones, and it is very difficult to identify them. But if you find one from the ground or buy it from a veteran, you know'.

Although high-end collectors generally have little interest in the kinds of decaying WWII artefacts to be found in Lapland, there are exceptions. One of our informants - who is not a dedicated collector but is very familiar with the militaria collecting world and active in amateur stewardship activities - described a 'salvage operation' demonstrating international interest in Lapland as a source of military material culture. The interviewee told us how he and his peers had learned - he did not specify how exactly - that some Central Europeans had come to Finland specifically to retrieve certain aeroplane parts which they knew could be found in a particular location. Our informant and some of his peers got to the site first, however, and moved and hid the parts elsewhere before the foreign expedition arrived. The informant also described two preceding cases where they had been too slow to respond to the foreign expedition and in one case had witnessed things disappearing from the sites and in the other case had seen large car parts transported across the Finnish border to Norway. Our informant suspected that such expeditions were organized based on 'orders' for specific kinds of military finds from international collectors - possibly generating considerable expense on the part of the organizers.

\section{High-end collecting, museums and 'alternative museums'}

Collectors, treasure hunters and others have varying attitudes to and relationships with the museum world and heritage professionals. There seems to be some frustration with heritage professionals and organizations on the part of at least some of our informants, whereas museum staff at the Provincial Museum of Lapland in Rovaniemi, which actively collects and displays material from WWII, have commented on the cooperative nature of several collectors.

One very active 'Expert-Explorer' - a former elementary school history teacher - has carried out impressive field and archival work on German sites in and around Rovaniemi. His data have been put to use in the Wir waren Freunde exhibition. On good terms with the museum staff, he has collaborated with them; he tells people that he is 'on museum business' when asked about his fieldwork. Although he 'hunts' for sites, collecting data instead of objects, his interests are encouraged by personal connection. Excited when he discovers previously unknown sites that most people thought would have been eradicated decades ago, the personal connection began in childhood when he played around these places: 'In the 1960s there was plenty of war junk around. Our home was located in the area where Organisation Todt used to be based and we found all kinds of things like a dagger from the potato field, and my brother brought a rusty airplane machine gun from the forest. We always played war or cowboys and Indians'.

Some WWII enthusiasts, on the other hand, are on less harmonious terms with museum staff, in a few cases displaying distrust and even suspicion towards professional museums (although there are many other examples of willing collaboration and communication with museum workers). Where it does occur, this 
suspicion can take different forms, but it is particularly interesting to see in this context how these attitudes have affected militaria collecting and even contributed to the formation of private collections and 'alternative museums'. One serious collector serves as an illustrative example. The collection in question is effectively a 'home museum'. The collector has very little interest in rusty earth finds and instead targets good-condition high-end objects: uniforms, knives, hats, helmets, photographs and books. His collectibles mostly come from the estates of soldiers who fought in WWII. Incidentally, estates are reportedly also the main source of WWII objects for antiques dealers in Rovaniemi. Perhaps most interestingly, however, the serious collector told us that many people had donated objects to him, apparently believing that he would take better care of them than professional museums. In museums the artefacts might end up 'buried' in storage rooms, and there seemed to be an assumption that museums would have no real interest in the objects. Unwillingness to trust the motivations or collection management strategies of museums is not unique to Lapland. Goddard (2008, 33), for example, noted distrust of archaeologists and museum professionals within some Mormon communities in Utah, USA, for a range of historical and complex reasons.

Our 'high-end' collector was evidently more of a 'collector type' than a 'Nazi fan' (cf. Kingsepp 2006); indeed, his militaria collecting activities - including things such as guns and tin soldiers - have developed to include certain types of WWII German militaria. He valued personal belongings and found it important to know the persons behind the objects. He had had personal contact with some old SS men locally, and was particularly interested in them and personal histories from Lapland. He displayed a vast collection of objects in a self-built home museum, with display cases and his own categorizations. It was clear that he had carefully planned the display of the objects and their histories. His collection is curiously known and unknown at the same time, for the collector welcomes certain people and selected small groups to visit there from time to time (there is even a guest book for visitors to sign), but in order to visit this 'museum', one needs to know people who know about it. Here, the owner seemed to be mostly concerned about security. Although he did not give any estimation of the total financial value of his collection, it was clear that it was substantial. Prices attached to objects from WWII can be high depending on the object and its condition; one interviewee estimated that an SS officer's dagger would be worth 5000-6000 euros.

\section{Discussion}

There are different and conflicting views on the value and meaning of WWII material culture in northern Finland. This was particularly clearly reflected in the debate that followed the organized campaigns, initiated by an environmental organization a decade ago (and discontinued a few years later), to clear off the 'war junk' to prevent it from 'spoiling' the natural beauty of Lapland (see Herva 2014). Newspaper features and the discussion of this issue on various internet forums demonstrate the divided opinions about WWII (and especially German) material culture decaying in Lapland landscapes. However, an important and telling thread that is present in online discussions and quite systematically taken up by our interviewees, irrespective of their personal background and specific perceptions of WWII and its heritage, is the emphasis put on local heritage significance. The various dimensions of these issues merit some further discussion and link Finnish Lapland to much broader topics related to alternative museology, archaeology and heritage.

Acquiring Nazi material culture is evidently an important field of global militaria collecting. The international fascination with Nazis, especially since the 1960s (e.g. Goodrick-Clarke 2002, 107-108), in its diverse forms, and often mediated by popular culture and its own mythology of Nazis (Kingsepp 2006; Rau 2013; see also below), has unavoidably affected the post-war and contemporary perceptions of German troops and their legacy in Finland. It should be observed, however, that the German troops based in Finland 
have generally not been referred to as 'Nazis' in local parlance (cf. Carr 2014 and this issue for a similar case on the Channel Islands), or seen through the 'evil Nazis' lens that for better or worse often dominates the representation of Hitler's Germany. Indeed, none of the WWII memorabilia collectors interviewed were what might be seen as 'Nazi enthusiasts' or appropriated the internationally dominant 'evil Nazis' discourse. Instead, the interest in German and other WWII heritage had primarily to do with local northern Finnish matters, experiences and identities; for instance, the peaceful co-existence of German troops and local civilians through the war from 1940 to 1944 was often emphasized.

Although our interviewees did not usually reflect more deeply on why they emphasized the local importance of this heritage, it makes sense against a number of broader issues. First, the Lapland War and northern Finnish experiences and perspectives of WWII have been marginalized in the national-level war narratives (Kivimäki 2012), and regarded as secondary to what the war was 'really' about, that is, the battle against the Soviet Union, which mainly unfolded elsewhere.

Even in Lapland, the Finnish national narrative, as well as the local narrative in Lapland itself, portrays the Soviets as the enemy due to partisan attacks that targeted civilians in Lapland, and due to the role of the Soviet Union in bringing about the Lapland War. At the same time, there is also a perception of the "'good Germans" who provided Finland with much needed help in a difficult time' (Herva 2014, 300). On a more general level, the marginalization of Lapland in the war narratives resonates with a much longer and broader tendency in Finland to regard the north of the country as remote, peripheral and generally less important than the southern 'heartlands'.

Lapland has been subject to colonial attitudes and practices since the early modern period (see Naum and Nordin 2013) and there is a degree of suspicion in northern Finland towards the politically, economically and otherwise dominant south of the country (e.g. Massa and Snellman 2003). It is against this background - as a reaction to southern dominance - that the tendency of our interviewees to highlight the local and regional importance of German WWII materialities in Lapland needs to be understood.

The real and imagined 'south-centrism' may also account, to some extent, for the apparent distrust of heritage authorities. In one case recounted to us, an informant told us of an incident that illustrates the northern impression of apathy from the responsible authorities. She recounted how Metsähallitus was planning to carry out logging in an area with abundant German military ruins, about which the officials had no idea but which the local villagers deemed an important part of their 'own' heritage. Our informant's ceaseless attempts to raise the officials' awareness of the site were rewarded when they finally visited the site and, impressed by the remains, halted the planned felling.

A key theme emerging from our interviews is the importance of the personal (in various senses and forms) when it comes to the meaning of collecting WWII objects and other engagements. For instance, personal first-hand contact with German soldiers who had served in Lapland, or their families, or Finns who had closely cooperated with them, could spark amateur/alternative practices, as well as providing a ready supply for collectors. Likewise, personal objects, and knowing the people behind the objects, were considered important. An implication of this, rather obviously, is that what the public finds important and interesting about the past and its remains can be quite different from the view of heritage professionals. For instance, heritage professionals have recently emphasized the importance of WWII sites as a potential source of historical information (Heinäaho and Rautiainen 2011), a means of knowing the past better, whereas non-professionals may value more immediate, closer encounters with the past and its material traces in the present. Whatever value non-professionals may otherwise attribute to abstract and 'academic' historical knowledge, there also seems to be a desire for more intimate encounters with the past, perhaps not so dissimilarly from how unearthing ancient statues in the Renaissance fascinated people due to the sense of a living presence and 'face-to-face' encounters with ancestors that realistic sculpture 
afforded (Barkan 1999, 55, 61; Godwin 2002, 14). Likewise, in modern museum settings, facial reconstructions of long-dead people - whether the Kennewick Man or the alleged King Philip II of Macedonia (Alexander the Great's father) - may be understood as attractive to the public because they afford a more readily personal and intimate contact with the past and its people than is enabled by conventional museum and heritage practices.

The professionally curated past and its material remains tend to be heavily mediated and sanitized, which unlike the experience of urban ruins (Edensor 2005), may distance people from the past by putting it literally and metaphorically behind glass walls. Many of our interviewees emphasized that the material remains of war should stay where they had been left, so that they can testify to the German presence in 1941-45, including the fact that the darker incidents that followed did actually happen: 'This is part of local history, no matter what', one interviewee observed. Moreover, the topics considered important in the learned and 'official' understanding of the past are not necessarily those that (all sectors of) the public find interesting and important, and amateur/alternative engagements, such as those discussed here, may be seen as a reaction to the professional distancing of the past.

Through treasure hunting and other related amateur and alternative engagements, it is possible for people to feel they have developed a more 'intimate' relationship with the past and its people, which was also reflected in our interviews. For instance, the amateur curator of a WWII vehicle talked about how he felt like he has, through his studies of the history of the vehicle, come to know the people who operated it during the war. These amateur engagements may, in some ways, be compared to the 'direct' engagement with the past, a desire to get 'into' the past or in a sense know it 'from the inside', which is arguably important to participants of historical re-enactments (see Daugbjerg, Eisner, and Knudsen 2014).

Of course, there is also a similar tendency within professional museums to promote less conventional approaches. The Wir waren Freunde exhibition in the Provincial Museum of Lapland decidedly sought to find a different way of representing the German military presence in Lapland from the traditional political and military-historical narratives. This included the sidelining of objects, although a selection of them were on display, and a prominent positioning of photographs. The curious and somewhat haunting animation of some persons in some of the photos on display (by means of a smart-phone application; Figure 5) illustrates the desire to - quite literally - bring the past alive and create face-to-face contacts. These 'living' wartime photographs strike an intriguing resonance with the metaphorical and experiential haunting qualities of the actual WWII material remains in Lapland landscapes (see Herva 2014).

Many of our interviewees also talked about 'treasures'. This might be taken as a (subconscious) reflection of the 'Nazi treasures' narratives which, like the 'evil Nazis', has been a recurrent theme in various forms after the war (e.g. Edsel 2013; Klein 2013), but is probably better understood as reflecting the fascination with discovering personally appealing objects and literally 'getting in touch' with the past. It is noteworthy that interviewees, with their very different backgrounds and interests, frequently referred to particular objects as treasures. One of our informants, for instance, who was not into militaria collecting and indeed actively discouraged people from taking 'souvenirs' (as she referred to them) from the German sites in her neighbourhood, had found what she thought was a make-up powder box in the remains of officers' barracks at a German camp site. On showing this to us, she exclaimed: 'Isn't this a treasure!', and then speculated on an officer's lady friend visiting the officers' quarters. Likewise, a veteran metal detectorist mentioned 'treasures' when showing us photos and talking about some of his finds; in his case, he treasured mostly the historical context and stories behind the finds, rather than their visual splendour.

It is clear from our interviews that the individual motivations for collecting and treasure hunting are complex and multiple - ranging from a notion of 'rescuing' WWII material culture from perceived ignorance and threat of destruction to highly personal connections and memories, and to more 'touristically oriented' 
souvenir hunting. As we have noted, despite recent increased attention from the museum community, notably the Provincial Museum of Lapland - and notwithstanding individuals who work closely with the heritage authorities - suspicion regarding the priorities, and indeed the ontologies, of these 'official' organizations continues to create a barrier to greater engagement and communication in some cases at least. The insight afforded by our own engagements with the different actors responding to and consuming the WWII cultural heritage of Finnish Lapland sheds important light on the variety of different drivers and opinions that can be at play, contributing to wider discussions of 'alternative' approaches to archaeology and non-institutional collection strategies.

Figure 5. One of the three interactive photographs in the Wir waren Freunde exhibition at the Provincial Museum of Lapland, Rovaniemi. The photograph 'comes to life' and talks to the visitor, with the aid of a smartphone application. Photo: Eerika Koskinen-Koivisto.

\section{Acknowledgements}

This article is part of the research project 'Lapland's Dark Heritage: Understanding the Cultural Legacy of Northern Finland's WWII German Materialities within Interdisciplinary Perspectives', based at the University of Helsinki, Finland, and funded by the Academy of Finland (Decision no. 275497). We thank the interviewees for kindly cooperating with our research, and thank the anonymous peer reviewers for their feedback on this article.

\section{Funding}

This work was supported by the Academy of Finland (Research Council for Culture and Society, decision no. 275497).

\section{Notes on contributors}

Vesa-Pekka Herva, PhD (2004, University of Oulu), is Professor of Archaeology at the University of Oulu, Finland. He has studied various aspects of material culture, human-environment relations, cosmology and heritage in north-eastern Europe from the Neolithic to the modern times.

Eerika Koskinen-Koivisto, PhD (2013, University of Jyväskylä), is a researcher in the project 'Lapland's Dark Heritage' at the University of Helsinki, Finland. She is an ethnologist/folklorist by training and is interested in the everyday life experiences of ordinary people in the post-war period, material culture, intergenerational exchange and narrative traditions.

Oula Seitsonen (MA, 2004, MSc, 2014, University of Helsinki) is a researcher in the project 'Lapland's Dark Heritage' at the University of Helsinki, Finland. His research interests cover a wide variety of subjects, ranging from prehistoric palaeoenvironmental studies to contemporary archaeology and digital humanities.

Suzie Thomas, PhD (2009, Newcastle University), is University Lecturer in Museology at the University of Helsinki, Finland. Her research interests include community archaeology, archaeology and amateur metal detecting, and alternative perspectives on cultural heritage.

\section{References}


Aikio-Puoskari, U., and P. Magga. 2010. Kylä kulttuurien risteyksessä: artikkelikokoelma Vuotson saamelaisista. Vuohču Sámiid Searvin 40-vuotisjuhlakirja [Village at the Intersection of Cultures: A Collection of Articles on the Vuotso Sámi. Vuohču Sámiid Searvi 40th Anniversary Book]. Vuohču Sámiid Searvi.

Alftan, R., ed. 2005. Aseveljet: saksalais-suomalainen aseveljeys 1942-1944 [Germans and Finns as Brothers in Arms 1942-1944]. Helsinki: WSOY.

Barkan, L. 1999. Unearthing the Past: Archaeology and Aesthetics in the Making of Renaissance Culture. New Haven: Yale University Press.

Bowman, B. A. 2008. "Transnational Crimes against Culture: Looting at Archaeological Sites and the 'Grey' Market in Antiquities." Journal of Contemporary Criminal Justice 24: 225-242.

doi:10.1177/1043986208318210.

Carr, G. 2014. Legacies of Occupation: Heritage, Memory and Archaeology in the Channel Islands. New York: Springer.

Colwell-Chantonphonh, C., J. Hollowell, and D. McGill. 2008. Ethics in Action: Case Studies in Archaeological Dilemmas. Walnut Creek: AltaMira Press.

Daugbjerg, M., R. S. Eisner, and B. T. Knudsen. 2014. "Re-Enacting the Past: Vivifying Heritage 'Again'." International Journal of Heritage Studies 20 (7-8): 681-687. doi:10.1080/13527258.2014.939426.

Edensor, T. 2005. "Waste Matter - The Debris of Industrial Ruins and the Disordering of the Material World." Journal of Material Culture 10 (3): 311-332. doi:10.1177/1359183505057346.

Edsel, R. M. 2013. The Monuments Men: Allied Heroes, Nazi Thieves, and the Greatest Treasure Hunt in History. New York: Little, Brown and Company.

Forrest, M. 2015. "70 Years after the War, Finland Looks Back." Barents Observer. http://barentsobserver.com/en/content/70-years-after-war-finland-looks-back

Garrett, B. L. 2015. "Urban Exploration as Heritage Placemaking." In Reanimating Industrial Spaces: Conducting Memory Work in Post-industrial Societies, edited by H. Orange, 72-91. Walnut Creek: Left Coast Press.

Goddard, J. 2008. “'Our' Legacies in Saving the Past.” Archaeological Review from Cambridge 23: 25-40. Godwin, J. 2002. The Pagan Dream of the Renaissance. Grand Rapids: Phanes.

Goodrick-Clarke, N. 2002. Black Sun: Aryan Cults, Esoteric Nazism and the Politics of Identity. New York: New York University Press.

Griffin, G. G. 1999. "Collecting Pre-Columbian Art." In The Ethics of Collecting Cultural Property: Whose Culture Whose Property? edited by P. M. Messenger, 103-115. Albuquerque: University of New Mexico Press.

Hart, S. M., and E. S. Chilton. 2015. "Digging and Destruction: Artifact Collecting as Meaningful Social Practice." International Journal of Heritage Studies 21: 318-335. doi:10.1080/13527258.2014.934267.

Heinäaho, H., and P. Rautiainen. 2011. "Romua vai sotahistoriallisia aarteita? [Mere Junk or Military Historical Treasures?]" Museo 2/2011: 32-34. 
Herva, V.-P. 2014. "Haunting Heritage in an Enchanted Land: Magic, Materiality and Second World War German Material Heritage in Finnish Lapland." Journal of Contemporary Archaeology 1: 297-321. doi:10.1558/jca.v1i2.2033.

Holtorf, C. 2004. "Doing Archaeology in Popular Culture." In The Interplay of Past and Present, edited by H. Bolin, 42-49. Hiddinge: Södertörns högskola.

Kingsepp, E. 2006. "Nazi Fans' but Not Neo-Nazis: The Cultural Community of 'WWII Fanatics." In Returning (to) Communities: Theory, Culture and Political Practice of the Communal, edited by M. Higgins and S. Herbrechter, 223-240. New York: Rodopi.

Kivimäki, V. 2012. "Between Defeat and Victory: Finnish Memory Culture of the Second World War." Scandinavian Journal of History 37: 482-504. doi:10.1080/03468755.2012.680178.

Klein, C. 2013. "\$1.35 billion in Nazi-looted art found in Munich." http://www.history.com/news/1-35billion-in-nazi-looted-art-found-in-munich

Koskinen-Koivisto, E., and S. Thomas. Forthcoming. "Lapland's Dark Heritage: Responses to the legacy of World War II." In Heritage in Action: Making the Past in the Heritage, edited by H. Silverman, E. Waterton, and S. Watson. New York: Springer.

Manacorda, S., and D. Chappell, eds. 2011. Crime in the Art and Antiquities World: Illegal Trafficking in Cultural Property. New York: Springer.

Mann, C., and C. Jörgensen. 2002. Hitler's Arctic War: The German Campaigns in Norway, Finland, and The USSR 1940-1945. Hersham: Ian Allan.

Massa, I., and H. Snellman, eds. 2003. Lappi: maa, kansat, kulttuurit [Lapland: Land, Peoples, Cultures]. Helsinki: Finnish Literature Society.

Naum, M., and J. M. Nordin, eds. 2013. Scandinavian Colonialism and the Rise of Modernity: Small Time Agents in a Global Arena. New York: Springer.

Olsson, H., J. Kokkila, and M. Hakanpää. 1999. Suomalaisten Waffen-SS vapaaehtoisten matrikkeli 19411943 [Register of the Finnish Waffen SS Volunteers 1941-1943]. Jyväskylä: Gummerus.

Pitblado, B. 2014. "An Argument for Ethical, Proactive, Archaeologist-Artifact Collector Collaboration." American Antiquity 79: 385-400. doi:10.7183/0002-7316.79.3.385.

Porter, C. 2008. "Natural History Discourse and Collections: The Roles of Collectors in the Southeastern Colonies of North America." Museum History Journal 1: 129-146. doi:10.1179/mhj.2008.1.1.129.

Rasmussen, J. M. 2014. "Securing Cultural Heritage Objects and Fencing Stolen Goods? A Case Study on Museums and Metal Detecting in Norway." Norwegian Archaeological Review 47: 83-107. doi:10.1080/00293652.2014.899616.

Rau, P. 2013. Our Nazis: Representations of Fascism in Contemporary Literature and Film. Edinburgh: Edinburgh University Press.

Robbins, K. J. 2013. "Balancing the Scales: Exploring the Variable Effects of Collection Bias on Data Collected by the Portable Antiquities Scheme." Landscapes 14: 54-72. doi:10.1179/1466203513Z.0000000006.

Sääskilahti, N. 2013. "Ruptures and Returns: From Loss of Memory to the Memory of a Loss." Ethnologia Fennica 40: 40-53. 
Thomas, S., O. Seitsonen, and V.-P. Herva. 2016. "Nazi Memorabilia, Dark Heritage and Treasure Hunting as 'Alternative' Tourism: Understanding the Fascination with the Material Remains of World War II in Northern Finland." Journal of Field Archaeology 41 (3): 331-343. doi:10.1080/00934690.2016.1168769.

Tuominen, M. 2005. "A Good World after All? Recovery after the Lapland War." In The North Calotte: Perspectives on the Histories and Cultures of Northernmost Europe, edited by M. Lähteenmäki and P. M. Pihlaja, Vol. 18, 148-161. Helsinki: Publications of the Department of History, University of Helsinki. 